\title{
As relações interdisciplinares entre Artes Visuais e Física/Astronomia: um olhar nas culturas indígenas e a questão da transposição didática
}

Leticia Laís Ducheiko leticia duc@hotmail.com $0000-0001-5932-2432$ Universidade Estadual de Ponta Grossa, Ponta Grossa, Paraná.

Josie Agatha Parrilha da Silva osieaps@hotmail.com

0000-0002-8778-6792

Universidade Estadual de Ponta Grossa,

Ponta Grossa, Paraná.

\author{
RESUMO
}

O objetivo da pesquisa foi desenvolver uma proposta interdisciplinar com conteúdo referente a cultura indígena a partir das áreas de Artes Visuais e da Astronomia. A teoria da Transposição Didática de Chevallard (2005) foi utilizada para embasar a pesquisa. A partir do entendimento que o material didático poderia ser um instrumento para realização da transposição didática, a pesquisa foi organizada em dois momentos. No primeiro momento, foi realizada uma pesquisa bibliográfica sobre as culturas indígenas, nas áreas de Artes Visuais e Astronomia e, no segundo momento, elaborou-se um material didático sobre a cultura indígena para ser utilizado no ensino escolar. Com esta pesquisa percebeu-se que em culturas indígenas, tanto os aspectos artísticos quanto os astronômicos estão interligados e que é possível unir a Arte e a Ciência das culturas indígenas no ambiente escolar a partir da transposição didática.
\end{abstract}

PALAVRAS-CHAVE: Arte indígena. Astronomia indígena. Transposição didática. 


\section{INTRODUÇÃO}

Este trabalho apresenta uma proposta interdisciplinar sobre o conteúdo da cultura indígena a partir das áreas de Artes Visuais e Astronomia. A temática da cultura indígena tornou-se obrigatória na educação básica de acordo com a Lei no 11.645 de 10 de março de 2008, e deve ser ministrada em todo o currículo escolar (BRASIL, 2008). No entanto, pelo pouco material didático existente e pela complexidade do tema, é necessário que o tema seja mais explorado para, na sequência, ser transposto didaticamente para o ensino escolar. Para embasar teoricamente a pesquisa, utilizou-se a Teoria da Transposição Didática de Chevallard (2005).

O objetivo da pesquisa foi o de desenvolver uma proposta interdisciplinar com conteúdo referente a cultura indígena a partir das áreas de Artes Visuais e Astronomia. Para isso, foi necessário verificar as relações existentes entre Artes Visuais e Astronomia nas culturas indígenas, e assim desenvolver um material didático que propiciassea transposição didática para o ensino escolar. A pesquisa organizou-se em dois momentos, no primeiro realizou-se uma pesquisa bibliográfica sobre as culturas indígenas, em especial, sobre suas Artes Visuais e seus conhecimentos astronômicos. No segundo momento, elaborou-se um folder informativo voltado para o ensino escolar, como material didático levando em consideração a transposição didática.

Com este trabalho, a partir das fontes bibliográficas pesquisadas (BEUTTENMÜLLER, 2002; CAMPOS, 2015; GARCEZ; OLIVEIRA, 2011) percebe-se que tanto os aspectos artísticos visuais quanto os astronômicos estão interligados em culturas indígenas, em especial na cultura Caiapó. Nesta cultura existe um ornamento em sua arte, utilizado em rituais, que revela além de sua mitologia, aspectos ligados aos seus conhecimentos astronômicos. Com a produção do material didático nota-se que é possível unir a Arte e a Ciência das culturas indígenas em um trabalho interdisciplinar, a partir de uma transposição didática, para o ensino escolar.

\section{Culturas indígenas, suas Artes Visuais e sua Astronomia}

No território onde hoje se encontra o Brasil, não há uma só cultura indígena, mas várias de diferentes povos que habitaram e habitam este território. Cada grupo indígena, cada etnia ou aldeia tem seus próprios costumes e forma de vida. Na região do Rio Paraná, se encontram os Guaranis e os Kaigangs, no litoral leste do Brasil habitavam os Tupinambás, os Botocudos e os Coroados, ao Sul do Rio Xingu se desenvolveram os Xavantes e mais ao Norte os Caiapó, isso relatando apenas alguns exemplos (BEUTTENMÜLLER, 2002).

Os números referentes à população indígena do Brasil antes da chegada dos colonizadores não são exatos. Garcez e Oliveira (2011) dizem que eram cerca de 5 
Nacional do Índio -FUNAI (2016) diz ter sido em torno de 3 milhões. O que se sabe é que a população indígena brasileira de 1500 até a década de 1970 teve um grande declínio e muitos povos foram extintos. No entanto, esse quadro começou a dar sinais de mudança nas últimas décadas do século XX e a população indígena voltou a crescer. Chegouem torno de apenas 70 mil na década de 1950 e subiu para mais de 800 mil em 2010, de acordo com a FUNAI (2016), mas ainda há muitos desafios a serem superados.

A respeito da situação dos indígenas, Santilli $(1996$, p. 2) explica que, do ponto de vista jurídico, tal situação "evoluiu da condição de indivíduos pouco capazes para a de membros de sociedades diferenciadas, detentoras de direitos especiais a serem protegidos nas suas relações com a sociedade-estado nacional".

Estas sociedades diferenciadas de que fala Santilli, guardam peculiaridades culturais. No que se referem aos seus conhecimentos astronômicos, os indígenas em geral baseavam-se ou baseiam-se nestes conhecimentos para orientação espacial, definição dos tempos de colheita, pesca e cerimoniais, mas cada povo à sua maneira e dentro do seu próprio contexto. No caso, por exemplo, dos Caiapós, não se pode mencionar uma astronomia Caiapó, mas uma ciência construída e integrada ao ambiente local que pode ser classificada como transdisciplinar (CAMPOS, 2015). Transdisciplinar justamente porque não se separa dos outros aspectos da cultura estandointegrada a eles, assim como ocorre com a arte indígena.

Garcez e Oliveira (2011) afirmam que a arte permeia todos os aspectos das culturas indígenas, tendo os objetos artísticos, em geral, alguma função prática ou ritual, mas ligadas ao prazer estético. Segundo essas autoras, o tempo e o esforço dedicado na produção de algum utensílio demonstram uma preocupação além da simples necessidade de uso. No entanto, para o indígena o que ele faz não é arte, mas manifestação da vida tribal, sendo que o julgamento artístico é externo, em função de seu caráter estético (BEUTTENMÜLLER, 2002). De acordo com Proença (2005, p. 90) "quando dizemos que um objeto indígena tem qualidades artísticas, o fazemos do nosso ponto de vista, e não do ponto de vista dos indígenas".

Proença (2005) afirma que as manifestações artísticas representam as tradições de uma comunidade e não as intenções do artista e, portanto, os estilos variam de um grupo para o outro. Dentre as manifestações artísticas indígenas estão a pintura corporal, a cerâmica, a tecelagem, a produção de cestos e balaios, as máscaras e os adereços e a arte plumária. A arte plumária que é constituída por peças feitas com penas de aves e usadas como enfeites, diademas, braceletes, brincos, pulseiras, colares e máscaras, é, para Beuttenmüller (2002, p. 14), "talvez seja a maior manifestação de arte dos índios do Brasil", já tendo sido exibida por exposições em várias partes do mundo.

$\mathrm{Na}$ arte plumária dos Caiapós encontra-se um objeto artístico, usado em rituais, chamado Mekutom, que demonstra a integração da arte desse povo com seus conhecimentos astronômicos. O Mekutom(Figura 1e 2) é um 'ornamentotexto' masculino usado em um ciclo cerimonial e está também ligado aos mitos dos Caiapós (CAMPOS, 2015). 


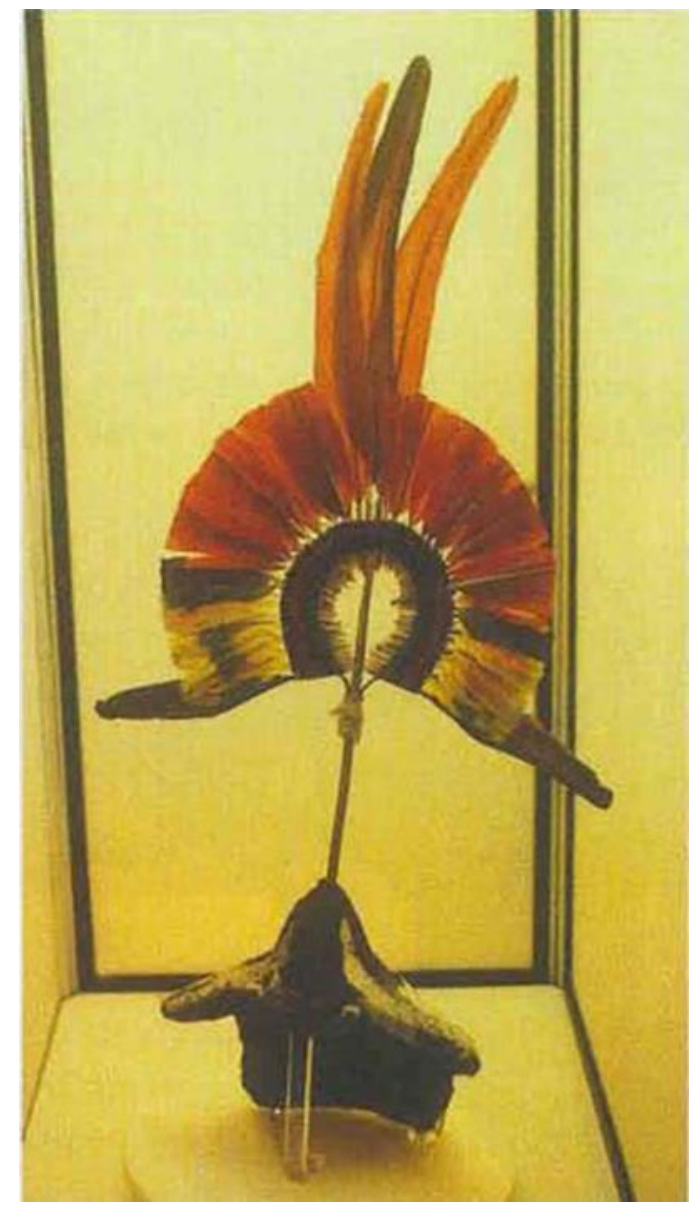

(Fonte: CAMPOS, 2015) 


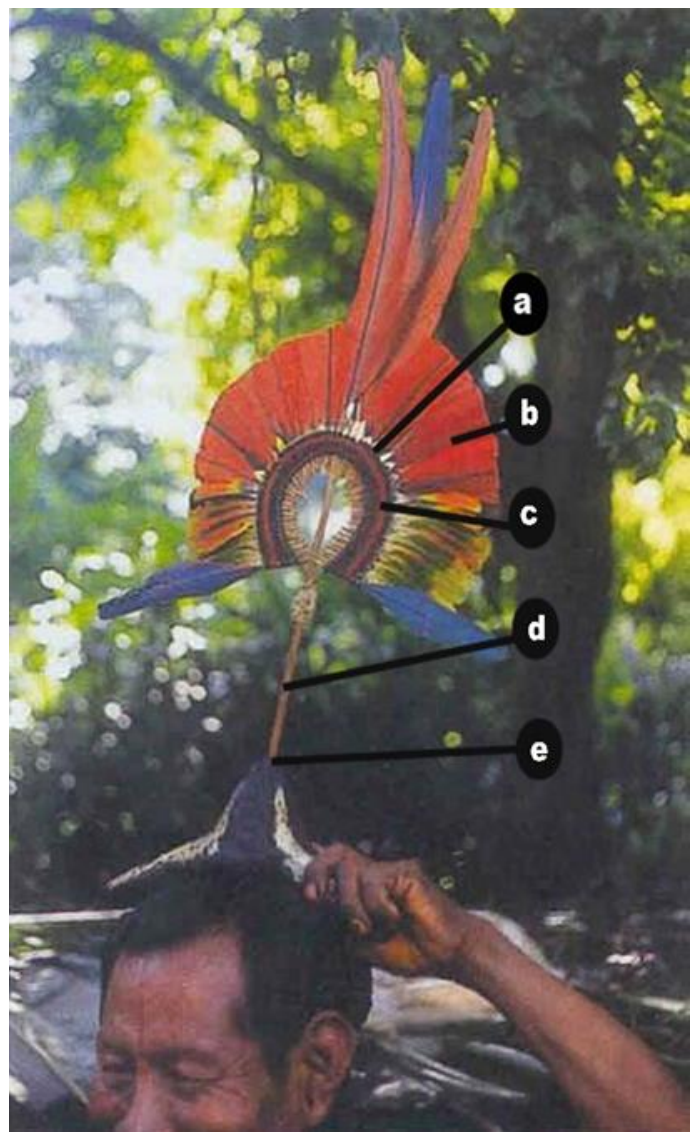

(Fonte: CAMPOS, 2015)

O Mekuton representa o universo Caiapó em termos de tempo e espaço com uma visão de "terra plana", segundo Campos (2015). Este autor explica que este universo é composto de várias camadas circulares e é simbolicamente representado pela estrutura de um ninho de vespas, que é como se fossem os horizontes ou os mundos Caiapós. De acordo com a mitologia do povo de Gorotire, a camada circular (pyka) onde eles vivem, foi descoberto por um caçador Caiapó que veio de uma camada superior e que, ao tentar caçar um tatu em sua toca, caçador e tatu caíram num vazio, mas o vento os levou de volta ao buraco. Do buraco ele avistou embaixo um mundo muito bonito, com grande quantidade de palmeiras de buriti (sinal de fartura de água). Com isso os antepassados resolveram descer para este outro buraco usando um cordão de algodão, mas como nem todos tiveram coragem para descer, as fogueiras dos que ficaram no mundo de cima ficam visíveis pelos que estão no mundo de baixo à noite, sendo as estrelas. Ao chegarem à camada inferior eles construíram uma aldeia circular e dizem que quando o Sol fica um disco preto, os faz lembrar o buraco pelo qual chegaram lá. Provavelmente isso se refere a um eclipse total do Sol. Ao lado do Sol está também Vênus, deusa que os ensinou a plantar os primeiros tubérculos (CAMPOS, 2015). Tal explicação é abordada à frente, no material didático em sua terceira página (Figura 5).

Segundo Campos (2015), no Mekuton, o arco que sustenta as penas representa as várias camadas dos mundos de cima(indicação a na Figura 2). As penas de arara-vermelha, arara-azul e papagaio se associam aos raios do Sol coloridos em algumas épocas e no pôr-do-sol(indicação b na Figura 2). A linha vermelha na armação representa o caminho do sol nascente ao sol poente neste 
mundo. Este alinhamento se situa no mesmo plano dos dois braços do capacete que indica Sul e Norte(indicação c na Figura 2). A vareta que liga o cocar ao capacete simboliza a corda de algodão utilizada pelos antepassados na descida(indicação dna Figura 2). O capacete é moldado com cera de abelha misturada com restos de vegetais secos e tem a forma de uma tartaruga de água doce ou tracajá. A parte mais elevada do capacete simboliza o centro do mundo e o local da primeira aldeia(indicação e na Figura 2).

Com o Mekutom podemos ver quão ligadas estão as questões estéticoartísticas desse ornamento com a visão de céu, mundo e orientação espacial desse povo indígena, tudo isto revelado através de sua mitologia e desse objeto artístico. Constitui-se então, um exemplo de união entre Arte e Ciência em culturas indígenas. Essa relação tem potencial para um fecundo trabalho interdisciplinar sobre a temática da cultura indígena no ambiente escolar, mas faz-se necessária uma transposição didática visto a sua complexidade. Essa transposição didática deve ser adequada para não formar nos alunos uma visão estereotipada e descontextualizada do tema.

\section{A transposição didática para o ensino escolar}

Ao falar de transposição didática um dos principais autores de referência é Yves Chevallard (1970-). A livro La TransposiciónDidáctica: Del Saber Sabio Al Saber EnseñadodeChevallard (2005), escrito originalmente em francês, é sua principal obra sobre esse tema, na qual o autor conceitua o termo transposição didática e apresenta suas principais considerações.

Chevallard (2005) discorre sobre três tipos de saber: o saber sábio, o saber a ser ensinado e o saber ensinado. Rodrigues (2012) diferencia estes saberes em: saber sábio como conhecimento científico; saber a ser ensinado sendo aquele que está presente nos programas educacionais e livros didáticos; e saber ensinado como aquele que se efetiva na sala de aula.Desse modo, o saber relacionado à cultura indígena é um saber sábio, à medida que é abordado como conhecimento científico; é um saber a ser ensinado, pois como previsto em lei deve estar nos currículos oficiais; e, portanto, necessita se efetivar como saber ensinado. $\mathrm{O}$ saber ensinado, de acordo Chevallard (2005) só ocorre com a transposição didática interna.

Para Chevallard (2005, p. 7, tradução nossa) a Transposição Didática ocorre "porque o funcionamento didático do saber é diferente do funcionamento acadêmico, porque há dois regimes do saber, inter-relacionados, porém não sobrepostos". No sistema didático não se pode compreender o que ocorre em seu interior se não levar em conta seu exterior, pois o sistema didático não existe se não for compatível com seu entorno. No entanto o que ocorre é a descontextualização do saber sendo que também o processo de despersonalização se realiza completamente durante o momento de ensino. $O$ saber que a transposição didática produz, de acordo com Chevallard (2005, p. 19, tradução nossa) é "um saber exilado de suas origens e separado de sua produção histórica na esfera do saber sábio, legitimando-se, em saber ensinado, como algo que não é de nenhum tempo e de nenhum lugar". 
Esse exílio do saber que é apontado por Chevallard (2005) também é apontado por Leivas e Cury (2009) quando afirmam que o saber é apresentado aos alunos como um saber neutro e sem fazer relação com as necessidades humanas. No entanto, tendo em vista que o contexto do ensino do saber é diferente do contexto em que o saber foi concebido, percebe-se que

Para que o ensino de um determinado elemento do saber seja meramente possível, esse elemento deverá haver sofrido certas deformações, que o farão apto para ser ensinado. O saber-tal-como-é-ensinado, o saber ensinado, é necessariamente distinto do saber-inicialmente-designado-como-o-quedeve-ser-ensinado, o saber a ensinar. Este é o terrível segredo que o conceito de transposição didática põe em perigo (CHEVALLARD, 2005, p. 17, tradução nossa).

Nesta relação entre saber sábio e saber a ensinar, as necessidades do ensino suscitam verdadeiras criações didáticas. Sendo que ocorre que

\begin{abstract}
Um conteúdo do saber que foi designado como saber a ensinar, sofre a partir de então um conjunto de transformações adaptativas que vão fazê-lo apto para ocupar um lugar entre os objetos de ensino. $O$ 'trabalho' que transforma um objeto de saber a ensinar em um objeto de ensino, é denominado transposição didática(CHEVALLARD, 2005, p. 45, tradução nossa).
\end{abstract}

Com estas transformações no conteúdo, o que acaba ocorrendo com frequência é uma enorme distância objeto do saber e o objeto de ensino. Para alguns, essa distância é perigosa, para outros é nela que ocorre o saber escolar (MARANDINO, 2004). O próprio Chevallard (2005), dedica um capítulo ao questionamento se a transposição didática é negativa ou positiva, sendo que a primeira reação imediata que se tem é que ela é percebida como algo mal e no menor dos casos como um mal necessário. A transposição didática é vista como uma violência ao ato de ensinar e há resistências a ela. A proposta do autor é passagem de uma reação pessimista para uma atitude otimista e dinâmica, disposta a buscar uma boa transposição didática, tendo na realidade um otimismo moderado. Desse modo ele não vê a transposição didática como negativa ou positiva, mas como necessária. $\mathrm{O}$ autor alerta que devemos nos abster de ensinar temas, mesmo que interessantes, se não temos uma transposição didática satisfatória, mas que há a exigência de buscar boas transposições didáticas, correspondentes à demanda da sociedade (CHEVALLARD, 2005).

A crise do sistema didático ocorre porque o saber ensinado se desgasta, pois com o tempo, o saber do sistema de ensino envelhece e já não é mais compatível com o entorno, com a sociedade. É isso que gera a desmotivação de professores, de alunos e dos pais. Para reestabelecer a compatibilidade torna-se indispensável a instauração de uma corrente de saber proveniente do saber sábio. Procura-se então um conjunto de modificações que restabeleçam a compatibilidade entre o global e o local, entre o sistema de ensino e seu entorno, entre a sociedade e a escola (CHEVALLARD, 2005).

Para Chevallard (2005) a chave da resolução da crise do sistema didático está na alteração de uma variável da relação didática: o saber. Para o autor existe algo como uma dualidade entre saber e alunos. É preciso restaurar o desejo de saber, a famosa motivação. Não se trata de uma simples reorganização por permutação, mas sim uma verdadeira refundação dos conteúdos. Com os elementos anteriores 
e os novos, advindos do saber sábio, é preciso construir um texto novo e ter uma integração aceitável entre uns e outros (CHEVALLARD, 2005).

No caso do saber sobre as culturas indígenas, ao tornar-se temática obrigatória nos currículos oficiais a partir de 2008, já passou pelo que Chevallard (2005) chama de Transposição Didática Externa (TDE) que é realizada pela noosfera(a noosfera inclui desde o presidente de uma associação de professores, até o professor que ministra as aulas, os pais dos alunos, os especialistas das disciplinas e os encarregados dos órgãos públicos) (CHEVALLARD, 2005). Para efetivar-se como saber ensinado na sala de aula, ainda se faz necessária a realização de uma Transposição Didática Interna (TDI), realizada pelo professor. 0 material didático constitui-se como uma ponte entre estas duas transposições didáticas.

\section{Material Didático: Artes Visuais e Astronomia nas culturas indígenas}

O material didático não substitui a transposição didática, mas é um instrumento na sua realização, auxiliando nas criações didáticas a serem feitas no momento da transposição. Criações didáticas são mais motivadoras, segundo Chevallard (2005), quando retornam ao saber sábio, acadêmico ou primário, ficando assim mais compatíveis com seu entorno e, portanto, mais contextualizadas. A interdisciplinaridade facilita a contextualização, pois não fragmenta o saber (FAZENDA, 2008). A partir desses princípios e de maneira interdisciplinar, criou-se o material didático na forma de um folder informativo voltado para o Ensino Fundamental, apresentado nas figuras 3, 4, 5 e 6.

Este folder inicia com um breve texto e uma ilustração demonstrando a diversidade das culturas indígenas no Brasil e segue com o questionamento sobre qual a relação entre Artes Visuais e Astronomia. Esse questionamento introduz ao material, pois os alunos, que em geral estão acostumados com um ensino disciplinarizado, sentem dificuldades inicialmente em relacionar Artes Visuais e Astronomia. 


\section{ARTES VISUAIS \\ \& ASTRONOMIA \\ NAS CULTURAS INDÍGENAS}

Não há uma

cultura

indígena, mas

várias.

Cada povo tem seus próprios custurmes e formas de vida.

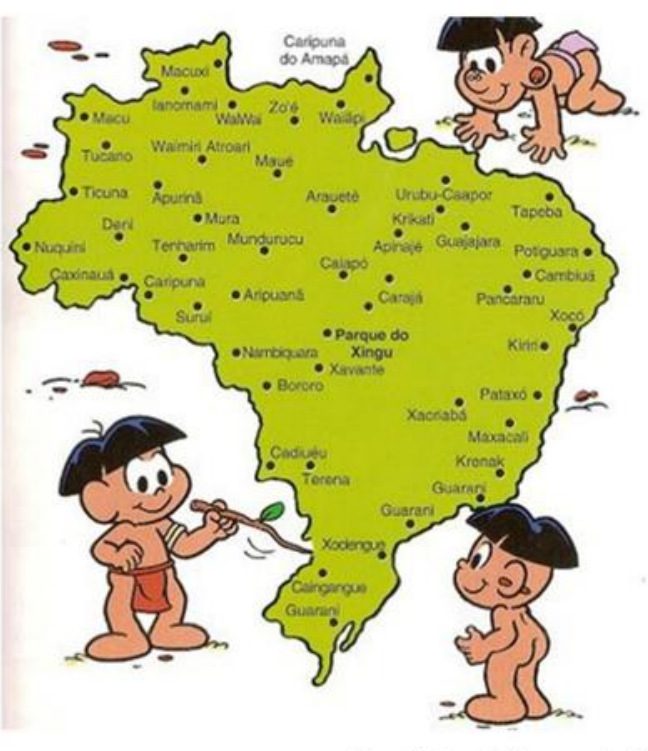

\section{Artes Visuais e Astronomia: qual a relação???}

Em culturas indígenas não há divisão em áreas do conhecimento. Astronomia e Arte permeiam todos os aspectos da cultura.

(Fonte: Elaborado pelos autores)

Na segunda página o folder exemplifica com imagens algumas formas de manifestações artísticas indígenas e uma frase reflexiva sobre o julgamento artístico feito a cerca destes objetos. É inserido, em seguida, informações sobre um objeto artístico particular dos Caiapós, o Mekutom. As informações sobre esse objeto continuam na página seguinte, abordando a mitologia em torno desse objeto e suas relações com a Astronomia, incluindo um tópico especial sobre a astronomia dos Caiapós. 


\section{Objetos Artísticos Indígenas}

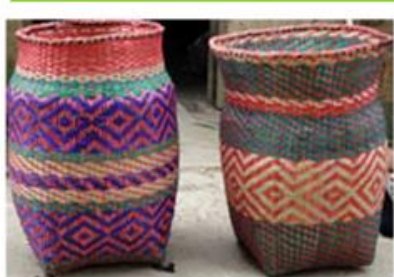

Figura 2 - Cestaria Guarani

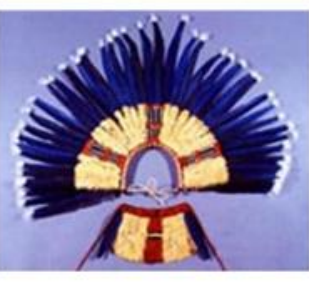

Flgura 3 - Arte Plumária

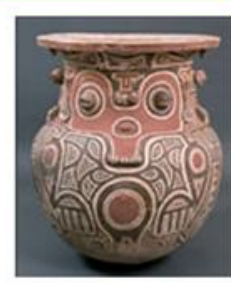

Figura 4 - Cerámica Marajoara

'Quando dizemos que um objeto indígena tem qualidades artísticas, o fazemos do nosso ponto de vista e não do ponto de vista do infdígena".

Você sabia que ...

Dos indígenas brasileiros, os Caiapós

são um grupo que mantém fortemente suas tradições.

Um objeto de sua arte plumária é o Mekutom.

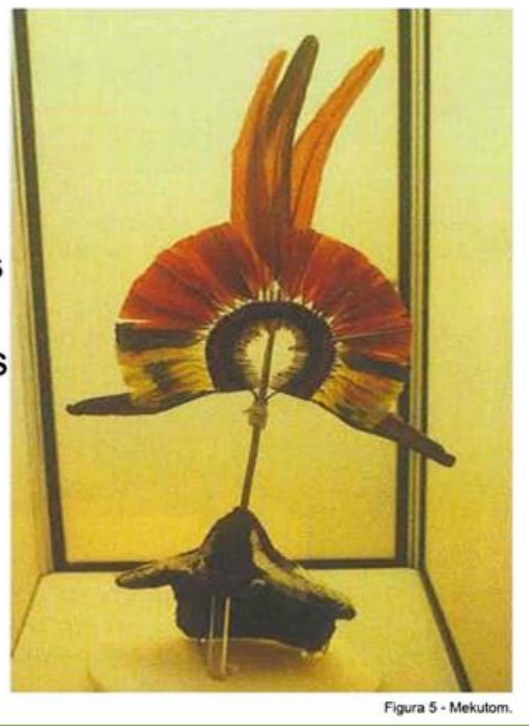

(Fonte: Elaborado pelos autores) 


\section{O Mekutom e a Mitologia}

O Mekuton representa o universo para os Caiapós com uma visão de "terra plana". Na sua mitologia é como se existissem várias camadas de terra e a camada que eles vivem foi descoberta por um caçador caiapó, que ao tentar caçar um tatu na camada superior caiu na sua toca e chegou a camada de baixo. Como nessa camada havia muita fartura, os antepassados resolveram descer.

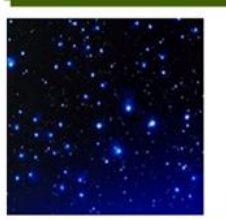

Para os Caiapós as estrelas são as fogueiras acesas pelos que não quiseram descer e quando o Sol fica um disco preto lembra o buraco pelo qual desceram.

O Sol como um disco preto é provavelmente um eclipse solar. O eclipse solar é um fenômeno que ocorre quando a Lua está entre a Terra e o Sol.
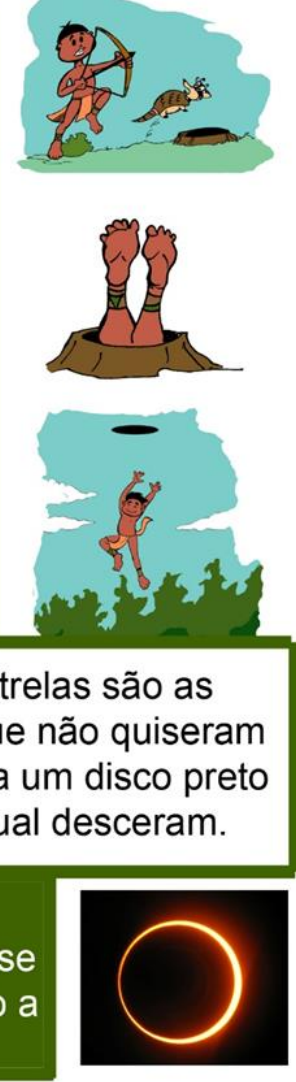

\section{Astronomia Caiapó}

Os caiapós utilizam seus conhecimentos astronômicos para orientação espacial e definição de tempos de colheita, pesca e cerimoniais.

(Fonte: Elaborado pelos autores)

Na última página há a indicação do que representa cada parte desse objeto abordado e é realizado um paralelo entre o seu uso para estes indígenas e um símbolo normalmente mais conhecido pelos alunos e utilizado com uma função de localização semelhante. Por fim, há uma conscientização sobre a não fragmentação do saber nas culturas indígenas. 
Mekuton e sua representação

a- $\mathrm{O}$ arco que sustenta as penas representa as várias camadas dos mundos de cima.

b- As penas de arara-vermelha, arara-azul e papagaio se associam aos raios do Sol.

c- A linha vermelha na armação representa o caminho do Sol nascente ao Sol poente. Este plano se situa no mesmo plano dos dois braços do capacete que indica Norte e Sul.

d- A vareta que liga o cocar ao capacete simboliza a corda utilizada pelos antepassados na descida. e- A parte mais elevada do capacete simboliza o centro do mundo e o local da primeira aldeia Caiapó.
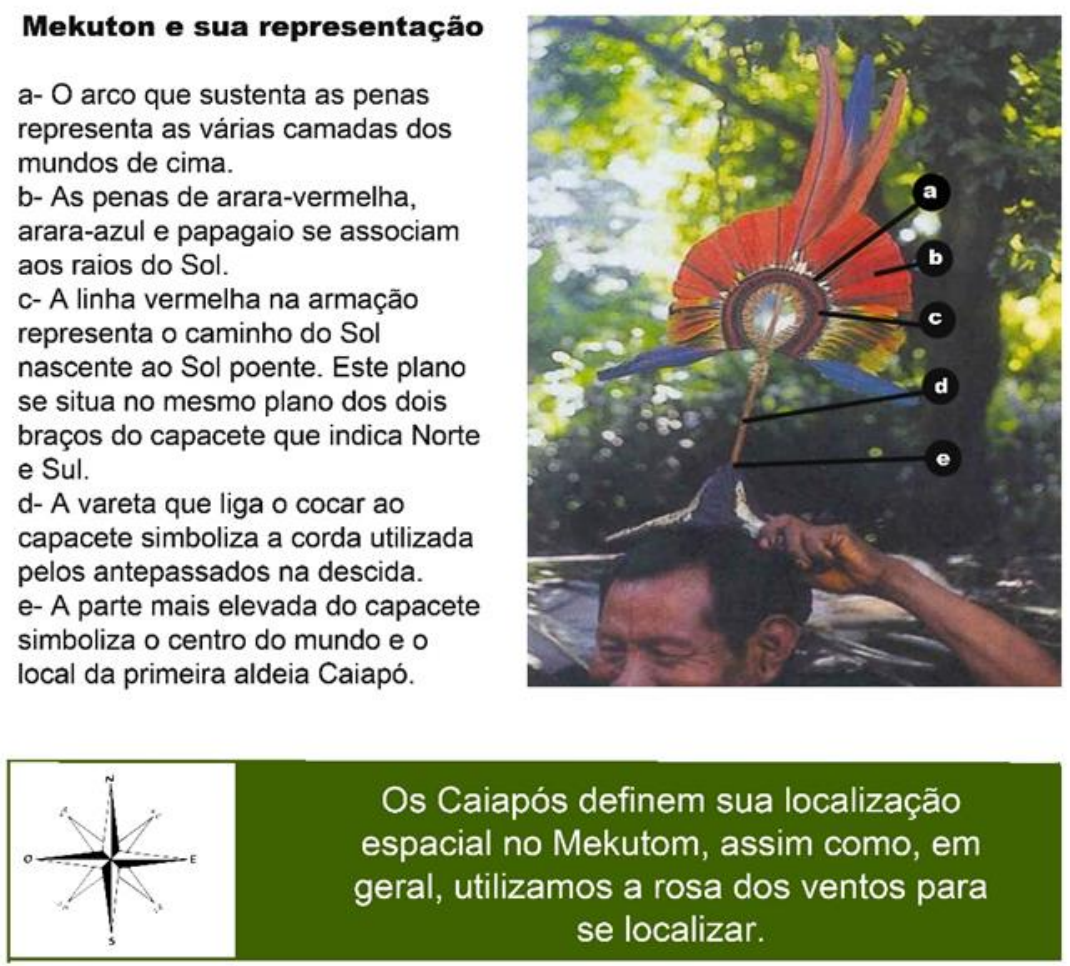

\section{No Mekutom estão presentes vários aspectos da cultura de um povo, que como outros povos indígenas nao separam os saberes em áreas do conhecimento.}



(Fonte: Elaborado pelos autores)

Para a elaboração do folder, além da temática da cultura indígena foram utilizados conteúdos específicos das duas áreas do saber envolvidas e relacionados de maneira interdisciplinar. Em Artes Visuais o conteúdo abordado é a Arte Indígena propriamente dita e em Astronomia, o conteúdo abordado são os Astros, os Movimentos Terrestres e os Celestes. Como todo o material didático, este é apenas um instrumento e aponta caminhos a serem seguidos e ampliados pelo professor em suas transposições didáticas. A abordagem interdisciplinar nesse material proporcionou uma menor despersonalização e descaracterização do 
saber envolvido, visto que não passou por uma disciplinarização, o que não existe em culturas indígenas.

\section{Considerações Finais}

A temática da cultura indígena no ensino escolar, além de obrigatória, é de grande importância para a conscientização dos alunos de que existem sociedades organizadas de modo diferenciado, inclusive em suas relações com o saber. 0 saber abordado de modo interdisciplinar não é neutro e está mais relacionado com as necessidades humanas. O revisitar o saber sobre a temática da cultura indígena verificando as relações interdisciplinares existentes entre Artes Visuais e Astronomia, auxilia no reestabelecimento da compatibilidade indispensável entre o saber sábio e o saber ensinado, causando assim uma verdadeira refundação dos conteúdos, que é exigência para a realização de uma boa transposição didática.

A proposta interdisciplinar realizada a partir do conteúdo referente à cultura indígena relacionando as áreas de Artes Visuais e Astronomia atende a uma demanda da sociedade, divulgando a produção de um material didático facilitador no processo da transposição didática para o ensino escolar.

Este trabalho demonstrou como a relação entre as Artes Visuais e os conhecimentos astronômicos em culturas indígenas estão interligados, não havendo disciplinarização e nem fragmentação dos conhecimentos. E, a proposta desenvolvida foi um pequeno recorte das inúmeras possibilidades que um tema rico, como a cultura indígena, pode oferecer para o ensino. É possível desenvolver outras propostas interdisciplinares que envolvam a matemática, ciências, português, entre outras áreas, contudo, é importante que todos esses conhecimentos contribuam para a compreensão e aproximação com essa cultura. Acreditamos que a inclusão da cultura indígena como um conteúdo de ensino, propiciara a divulgação, apreciação, valorização e manutenção de um patrimônio cultural brasileiro. 


\title{
Interdisciplinary relations between Visual Arts and Physics/Astronomy: a look at the indigenous cultures with a didactic transposition
}

\begin{abstract}
The objective of the research was to develop an interdisciplinary approach with content related to indigenous culture from the areas of Visual Arts and Astronomy. The theory of Didactic Transposition byChevallard (2005) was used to support the research. From the understanding that the didactic material could be an instrument for carrying out the didactic transposition, the research was organized in two stages. At first, a bibliographical research on indigenous cultures was carried out in the areas of Visual Arts and Astronomy and the second time, elaborated a didactic material about the indigenous culture to be used in school education. This research was realized that indigenous cultures in both the artistic aspects as the astronomical are interlinked and that it is possible to combine the Art and Science of indigenous cultures in the school environment from the didactic transposition.
\end{abstract}

KEYWORDS: Indigenous art. Indigenous astronomy. Didactic transposition. 


\section{REFERÊNCIAS}

BEUTTENMÜLLER, A. F. Viagem pela Arte Brasileira. São Paulo: Aquariana, 2002.

BRASIL. Lei 11.645, de 10 de marco de 2008. Disponível em: <http://www.planalto.gov.br/ccivil_03/_ato2007-2010/2008/lei/l11645.htm>. Acesso em: 06 de ago. de 2015.

BRASIL. Fundação Nacional do Índio. FUNAI. Disponível em: <>. Acesso em: 17 de maio de 2016.

CAMPOS, M. D. A cosmologia dos Caiapó. Disponível em:

<http://www.sulear.com.br/texto11.pdf>. Acesso em: 06 de abr. de 2015.

CHEVALLARD, Y. La transposicióndidáctica. 3ae ed. 2a reimp. Buenos Aires: Aique Grupo Editor, 2005.

FAZENDA, I. (org). O que é interdisciplinaridade? São Paulo: Cortez, 2008.

GARCEZ, L.; OLIVEIRA, J. Explicando a Arte Brasileira. Rio de Janeiro: Nova Fronteira, 2011.

LEIVAS, J. C. P.; CURY, H. N. Transposição Didática: Exemplos em Educação Matemática. Educação Matemática em Revista. Rio Grande do Sul, v. 1, n. 10, p. 65-74, 2009.

MARANDINO, M. Transposição Didática ou Recontextualização? Sobre a produção de saberes na educação em museus de ciência. Revista Brasileira de Educação. Rio de Janeiro, v. 1, n. 26, mar./ago. 2004

PROENÇA, G. Descobrindo a História da Arte. São Paulo: Ática, 2005.

RODRIGUES, T. C. Polímeros naturais e sintéticos: uma abordagem das características a partir de uma transposição didática. 2012. 50 f. Trabalho de Conclusão de Curso (Ensino de Química) - Universidade de Brasília, Brasília, 2012. 1996. 
Como citar:

DUCHEIKO, L. L.; SILVA, J. A. P. As relações interdisciplinares entre Artes Visuais e Física/Astronomia: um olhar nas culturas indígenas e a questão da transposição didática. Revista Brasileira de Ensino de Ciência e Tecnologia, v. 10, n. 2, 2017. Disponível em: <https://revistas.utfpr.edu.br/rbect/article/view/4035>. Acesso em: $x x x$.

Correspondência:

Direito autoral: Este artigo está licenciado sob os termos da Licença Creative Commons-Atribuição 4.0 Internacional.

\section{(c) (1)}

